\title{
Microbial and chemical quality of selected dried fish varieties available in Sri Lankan market
}

\author{
P.H. Ginigaddarage*1, I.H.W. Surendra ${ }^{2}$, W.K.S.R. Weththewa ${ }^{3}$, K.W.S. Ariyawansa ${ }^{1}$, G.J. \\ Ganegama Arachchi ${ }^{1}$, B.K.K.K. Jinadasa ${ }^{1}$, K.S. Hettiarachchi ${ }^{1}$ and E.M.R.K.B. Edirisinghe ${ }^{2}$ \\ ${ }^{1}$ National Aquatic Resources Research and Development Agency (NARA), Crow Island, Colombo \\ 15, Sri Lanka \\ ${ }^{2}$ Faculty of Applied Sciences, Rajarata University of Sri Lanka, Mihintale 50300, Sri Lanka \\ ${ }^{3}$ Department of Food Science and Technology, Wayamba University of Sri Lanka, \\ Makandura, Gonawila 60170,Sri Lanka. \\ *Correspondence (hasangi_g@yahoo.com) \\ http://orcid.org/0000-0003-4815-719X
}

\begin{abstract}
Dried fish is one of the traditionally preserved foods in Sri Lanka.Since dried fish is often an important component of daily meal, this study was aimed to assess the quality of selected dried fish varieties in the local market. Dried fish samples of nine selected varieties were collected under three categories, viz. locally produced, imported dried fish before and after distribution to retail market. They were analyzed for microbiological and chemical parameters. Water activity of the samples was also measured. Samples were found to be negative for Escherichia coli, Staphylococcus aureus and halophilic bacteria. Aerobic Plate Count and yeast and mould count of the majority of the samples were within the acceptable limit. Histamine content exceeded $100 \mathrm{mg} / \mathrm{kg}$ level in $33 \%$ and $13 \%$ of imported and local samples respectively. Water activity of the samples was $<0.75$ except for imported prawn samples of retail outlets. There was no significant difference $(p>0.05)$ between the analyzed parameters of all three categories.
\end{abstract}

Keywords: dried fish, histamine, microbiological quality, salt

\section{INTRODUCTION}

Seafood acts as a main component in the diet of most countries around the world and contributes as a main supply of animal protein. $17 \%$ of the animal protein intake of humans globally, is derived from seafood. In Sri Lanka 55\% of the animal protein intake is from fish and fishery products (FAO 2012). Since fish is a highly perishable food, most fish tend to spoil within few hours after capture at tropical temperatures. Therefore, as a measure to prevent the spoilage, fish should be processed or preserve quickly. Cooking, lowering moisture content by salting, smoking and drying and lowering the $\mathrm{pH}$ are the methods which can be used to preserve fish (Fellows and Hampton 1992).

Drying is regarded as a traditional method of preservation of fish. In Sri Lanka dried fish is one of the oldest processed foods. In 2014,the total dried fish production of Sri Lanka was 71,810 tonnes while imported amounts of dried fish were 35,280 tonnes and 33,000 tonnes in 2014 and 2015 respectively (MOFAR 2016).

The quality of dried fish is affected by the presence of microorganisms. Determination of microbiological quality of dried fish and other processed fish becomes very important when the consumer's health and hygiene is considered (Lilabati et al. 1999). Fungi are one of the major groups of microorganisms which affect the quality of dried fish, especially along the distribution channel from manufacturer to the consumer's end (Chakrabarti and Varma 2003) causing off flavours, softening of the flesh and some producing potentially dangerous mycotoxins when conditions are favourable for fungal growth (FAO 1982). Common sources of contamination include dust in and around fish processing place, contaminated coastal water and soil and unhygienic handling (FAO 1982; Prabhakaran and Gupta 1990).

Histamine is a chemical compound found in spoiled scombroid fish and other marine fish contain high levels of histidine which is a free amino 


\section{P.H. Ginigaddarage et al.}

acid in the fish muscle (Pan and James 1985). Formation of histamine, which can cause health problems, is a result of time and temperature abuse (USFDA 2011). High degree of bacterial and fungal contamination and elevated histamine levels in dried fish has been reported in a previous study done in Sri Lanka (Ranasinghe et al. 2014).

Since dried fish plays a major role in Sri Lankan diet as a rich source of protein and a popular food item among people, it is very important to evaluate its microbial and chemical quality. Therefore, this study was done to assess the microbiological and chemical quality of selected varieties of both locally manufactured and imported dried fish available in the local market.

\section{MATERIALS AND METHODS}

A total of 71 dried fish samples of selected varieties namely; tuna (Katsuwonus pelamis), sprats (Stolephorus sp.), catfish (Arius sp.), sailfish (Istiophorus sp.), katta (Scomberoides lysan), shark (Carcharhinus sp.), prawns (Penaeus sp.), herrings (Amblygaster sp.) and pannawa (Johnius sp.) were obtained from locally produced dried fish $(n=52)$, imported dried fish before distributing to the local market $(n=19)$ and imported dried fish being sold at the local market $(n=27)$ during March - November 2014. Each sample was weighed approximately 500 $\mathrm{g}$ and transferred into polythene bags and transported to the laboratory. Samples were analyzed for microbiological (Aerobic Plate Count or APC, Total Coliforms, E.coli, Staphylococcus aureus, yeast and mould, halophilic count) and chemical (salt, histamine; for histamine forming varieties only) parameters. Water activity of the samples was measured according to ISO 21807:2004 (E) standard (ISO 2004) using Novasina AW sprint water activity meter.

\section{Aerobic Plate Count (APC)}

APC was carried out using SLS 516: Part 1:1991 (SLS 1991a).Ten grams of the sample was weighed aseptically into a sterile stomacher bag and $90 \mathrm{ml}$ of diluents (maximum recovery diluents - Oxoid) was added and blended in a stomacher blender for 1-2 minutes to make up the $10^{-1}$ dilution. Four dilutions were used starting from the $10^{-2}$ dilution for plating. $1 \mathrm{ml}$ of $10^{-2}$ dilution was transferred to each of the two sterile petri plates using sterile pipettes. Same procedure was repeated with the other dilutions. About $15 \mathrm{ml}$ of standard plate count agar (Oxoid) medium at $45 \pm 0.5^{\circ} \mathrm{C}$ was poured into each petri plate and mixed with the inoculums and allowed to solidify. Plates were incubated at $37^{\circ} \mathrm{C}$ for 48 hours. After the incubation period, bacterial count was taken. $\mathrm{NaCl}(0.5 \%)$ was added to the culture media. Media control and air control were carried out in parallel to the analysis as internal quality control.

\section{Yeast and mould}

SLS 516: Part 2: 1991 (SLS 1991b) method was used to enumerate yeast and mould. Sample preparation was done as mentioned in the APC method and spread plate method was used. One millilitre of the $10^{-2}$ dilution was transferred on to the surface of previously prepared Potato Dextrose Agar (PDA) plates. Four dilutions were tested. Then the plates were incubated at $25 \pm 1^{\circ} \mathrm{C}$ for 5 days. After the incubation colonies were counted using colony counter. Here too, media control and air control were carried out in parallel to the analysis as internal quality control.

\section{MPN method for coliforms and $E$. coli}

For enumeration of coliforms, and E. coli SLS 516: Part 3: 1982 method was used. Ten grams of the dried fish sample was weighed in a sterile stomacher bag and $90 \mathrm{ml}$ of the diluent (maximum recovery diluent-Oxoid) was added and blended. Then $10 \mathrm{ml}$ of the $10^{-1}$ dilution was inoculated into each three tubes containing $10 \mathrm{ml}$ of double strength MacConkey broth purple (Oxoid). Then $1 \mathrm{ml}$ of each $10^{-1}$ dilution was inoculated to each three tubes containing $10 \mathrm{ml}$ of single strength MacConkey broth purple. The same procedure was repeated for $10^{-2}$ and $10^{-3}$ dilutions. Tubes were incubated at $36 \pm 1^{\circ} \mathrm{C}$ to $24-48$ hours. Tubes were examined for acid and gas production. Tubes showing acid and gas production after incubation is considered as presumptive positive for coliforms. Positive tubes were sub cultured into two tube sets containing 10 $\mathrm{ml}$ of Brilliant Green Bile Broth and one set was incubated at $36 \pm 1^{\circ} \mathrm{C}$ for 48 hours for total coliforms and the other tube set was incubated at $44 \pm 0.1^{\circ} \mathrm{C}$, for 48 hours for faecal coliforms. The tubes with gas production were considered as positive results. 


\section{P.H. Ginigaddarage et al.}

From the positive faecal coliform tubes loop full of cultures were streaked onto eosin methylene blue agar (Oxoid) and incubated at $36 \pm 1{ }^{\circ} \mathrm{C}$ for 24 hours. Typical E. coli colonies were examined and colonies were inoculated into tubes containing peptone water and incubated at $44 \pm 0.1^{\circ} \mathrm{C}$ for $24-48$ hours. Production of indole was tested by adding indole reagent. Cultures showing indole production were considered as E. coli positive cultures. E.coli pure culture as the positive control and Staphylococcus aureus as the negative control was inoculated into broth tubes parallel to the analysis.

\section{Enumeration of Staphylococcus aureus}

SLS 516: Part 6: 1992 (SLS 1992) method was used to enumerate $S$. aureus. Sample preparation was done as mentioned in the APC method. $1 \mathrm{ml}$ of the $10^{-1}$ dilution was transferred on the surface of three small previously prepared Baird-Parker agar plates $(90 \mathrm{~mm})$. Then the plates were incubated at $37 \pm 1^{\circ} \mathrm{C}$ for 18-24 hours. After the incubation typical and atypical colonies were selected and confirmation was done using the coagulase test. For the coagulase test inoculum was transferred to a tube containing brain heart infusion broth and incubated at $37 \pm 1{ }^{\circ} \mathrm{C}$ for 20 - 24 hours. Then the $0.1 \mathrm{ml}$ of each culture was added aseptically to $0.3 \mathrm{ml}$ of the rabbit plasma in sterile tubes and incubated at $37 \pm 1^{\circ} \mathrm{C}$. Clotting of the plasma was examined after 4-6 hours. S. aureus pure culture was used as the positive control.

\section{Halophilic bacterial count}

Halophilic bacteria was enumerated using the method prescribed in SLS 643:2007. $50 \mathrm{~g}$ of the sample was blended with halophilic broth and 0.1 $\mathrm{ml}$ of each dilution was placed on halophilic agar plates with the spread plate technique. Plates were incubated at $33-35^{\circ} \mathrm{C}$ for $5-12$ days. Media control and air control were carried out parallel to the analysis as internal quality control.
Determination of salt content (SLS 643:2007; SLS 2007)

One gram of the dried sample was weighed to the nearest milligram, into a $250 \mathrm{ml}$ Erlenmeyer flask. $50.0 \mathrm{ml}$ of standard silver nitrate solution and $20 \mathrm{ml}$ of dilute nitric acid were added and boiled on a hot plate for about 45 minutes until all soluble solids are dissolved. Then it was allowed to cool and $50 \mathrm{ml}$ of distilled water and $5 \mathrm{ml}$ of indicator solution was added. Then the titration was done against standard potassium thiocyanate solution until a permanent brown colour appeared. The salt content was then calculated as follows:

Salt content $($ as $\% \mathrm{NaCl})=\frac{5.85\left(\mathrm{~V}_{1} \mathrm{~N}_{1}-\mathrm{V}_{2} \mathrm{~N}_{2}\right)}{\mathrm{m}}$ where, $\mathrm{V}_{1}=$ Volume in $\mathrm{ml}$ of the standard silver nitrate solution used; $\mathrm{N}_{1}=$ concentration of the standard silver nitrate solution; $\mathrm{V}_{2}=$ volume in milliliters of the standard thiocyanate solution used; $\mathrm{N}_{2}=$ concentration of the standard thiocyanate solution; and $\mathrm{m}=$ mass, in grams of the dried sample taken.

\section{Determination of histamine content}

Histamine was determined by the method described in Jinadasa et al. (2015). High-performance liquid chromatography (HPLC) model Shimadzu, SIL $20 \mathrm{~A}$ was used to analyze samples. Ten grams of the sample was blended in $20 \mathrm{~mL}$ of $10 \%$ trichloroacetic acid solution and $20 \mathrm{~mL}$ of distilled water for 30 seconds. Final volume was made up to $100 \mathrm{~mL}$ with distilled water and filtered through a Whatman No. 1 filter paper. Ten millilitres of the filtered sample was passed through Amberlite CG-50 resin. Fluorophore standards and samples were prepared by mixing $5 \mathrm{~mL}$ of column chromatography elute with $0.1 \%$ O-Phthaldialdehyde solution. For each injected batch, a set of five standards with a concentration of $0.5,1.0,1.5,2.0$ and $3 \mathrm{mg} / \mathrm{mL}$ of histamine and a recovery sample were run at the beginning. Samples were done in duplicates. Concentration of histamine $(\mathrm{mg} / \mathrm{kg})$ was calculated by using the following equation.

Histamine concentration $(\mathrm{mg} / \mathrm{kg})=\frac{\text { Measured concentration of histamine in extract }\left(\frac{\mathrm{mg}}{\mathrm{L}}\right)}{\text { Sample weight }(\mathrm{g})} \times 100$

This work licensed under a Creative Commons Attribution-NonCommercial 4.0 International License 


\section{P.H. Ginigaddarage et al.}

\section{RESULTS}

According to microbiological results obtained (Table 1), samples of all three categories were negative for $E$. coli, $S$. aureus and halophilic bacteria. Total coliforms were absent in all locally produced samples. Of the 46 imported samples examined, three samples were detected with total coliforms both before and after distribution to retail outlets but were less than $100 \mathrm{MPN} / \mathrm{g}$ in two samples. One sprat sample had $>1100 \mathrm{MPN} / \mathrm{g}$. APC of locally manufactured samples were in the range of $1.7 \times 10^{4}-2.0 \times 10^{7} \mathrm{cfu} / \mathrm{g}$ and imported samples both before and after distribution to the market had $9.0 \times 10^{2}-2.4 \times 10^{8}$ and $7.6 \times 10^{4}-9.7 \times 10^{6} \mathrm{cfu} / \mathrm{g}$ respectively.

Table 1 Microbiological parameters of dried fish samples analyzed. Sample types: I - Locally manufactured dried fish samples; II - Imported dried fish samples before distribution; III - Imported samples available at the retail market. ND - Not detected.

\begin{tabular}{lrrrrrr}
\hline $\begin{array}{l}\text { Sample } \\
\text { type }\end{array}$ & APC (cfu/g) & $\begin{array}{r}\text { Total coliform } \\
(\mathrm{MPN} / \mathrm{g})\end{array}$ & $\begin{array}{r}\text { E. coli } \\
(\mathrm{MPN} / \mathrm{g})\end{array}$ & $\begin{array}{r}\text { S. aureus } \\
(\mathrm{cfu} / \mathrm{g})\end{array}$ & $\begin{array}{r}\text { Yeast and mould } \\
(\mathrm{cfu} / \mathrm{g})\end{array}$ & $\begin{array}{r}\text { Halophilic } \\
\text { bacterial count } \\
(\mathrm{cfu} / \mathrm{g})\end{array}$ \\
\hline I & $1.7 \times 10^{4}-2.0 \times 10^{7}$ & $\mathrm{ND}$ & $\mathrm{ND}$ & $<1.0 \times 10^{1}$ & $1.0 \times 10^{1}-6.0 \times 10^{4}$ & ND \\
II & $9.0 \times 10^{2}-2.4 \times 10^{8}$ & ND $->1100$ & ND & $<1.0 \times 10^{1}$ & $8.5 \times 10^{1}-3.0 \times 10^{3}$ & ND \\
III & $7.6 \times 10^{4}-9.7 \times 10^{6}$ & ND - 9 & ND & $<1.0 \times 10^{1}$ & $2.0 \times 10^{1}-8.0 \times 10^{3}$ & ND \\
\hline
\end{tabular}

In locally manufactured samples $58 \%$ of samples contained APC less than $1.0 \times 10^{5}$ which is acceptable. $33 \%$ of the samples had APC more than $5.0 \times 10^{5} \mathrm{cfu} / \mathrm{g}$ which is unacceptable. $60 \%$ of the imported samples obtained from the retail outlets were acceptable in terms of APC with counts $<1.0 \times$ $10^{5} \mathrm{cfu} / \mathrm{g} .22 \%$ were in the rejection level $\left(>5.0 \times 10^{5}\right.$ $\mathrm{cfu} / \mathrm{g}$ ). APC of imported samples before distribution had $68 \%$ and $21 \%$ in the acceptable, and rejection limits respectively. According to SLSI limits yeast mould count of dried fish is acceptable if the count is $<1000 \mathrm{cfu} / \mathrm{g}$ and unacceptable if it is greater than $10,000 \mathrm{cfu} / \mathrm{g}$. In locally manufactured samples $92 \%$ were good in quality and $4 \%$ were of bad quality. In imported samples obtained from retail outlets $82 \%$ were of good quality and $7 \%$ were in the rejection limit. $84 \%$ of the imported samples before distribution contained yeast and mould count in acceptable levels and $16 \%$ of the samples were in the rejection level.

According to Table 2, it can be seen that highest acceptable percentage $(68 \%)$ of dried fish in terms of APC belongs to the imported samples before distribution. In yeast and mould count highest acceptable percentage $(92 \%)$ is from locally manufactured samples. Thirty three percent of the locally manufactured dried fish were in the unacceptable APC levels. Imported samples before distribution had the highest unacceptable percentage (16\%) of yeast and mould count. When considering samples of all three categories $55.7 \%$ of locally manufactured, $52.6 \%$ of imported before distribution and $55.5 \%$ imported after distribution, were in the acceptable range for all the microbiological specifications mentioned in SLS.

Table 2 Acceptability percentages of dried fish based on APC and yeast and mould counts. I Locally manufactured dried fish samples; II Imported dried fish samples before distribution; III - Imported samples available at the retail market.

\begin{tabular}{lcccc}
\hline $\begin{array}{l}\text { Sample } \\
\text { type }\end{array}$ & \multicolumn{2}{c}{ Acceptable \% } & \multicolumn{2}{c}{ Unacceptable \% } \\
\cline { 2 - 5 } & APC & $\begin{array}{c}\text { Yeast } \\
\text { \&mould }\end{array}$ & APC & $\begin{array}{c}\text { Yeast } \\
\text { \&mould }\end{array}$ \\
\hline I & 58 & 92 & 33 & 4 \\
II & 68 & 84 & 21 & 16 \\
III & 60 & 82 & 22 & 7 \\
\hline
\end{tabular}

Thirty three percent of imported dried fish samples and $13 \%$ of local samples exceeded 100 $\mathrm{mg} / \mathrm{kg}$ level which is the maximum recommended limit for histamine content according to SLSI standard. According to Table 3, it can be seen that the average values of histamine content is high in the both categories of imported tuna samples. Nevertheless, in hurulla (Amblygaster) samples, locally manufactured samples showed a high average value. Sprat samples showed a less amount of histamine. 


\section{P.H. Ginigaddarage et al.}

Table 3 Average histamine values $(\mathrm{mg} / \mathrm{kg})$ of selected dried fish species. I - Locally manufactured dried fish samples; II - Imported dried fish samples before distribution; III - Imported samples available at the retail market.

\begin{tabular}{lrrr}
\hline Sample type & Tuna & Hurulla & Sprat \\
\hline I & 57.0 & 94.0 & 5.6 \\
II & 134.0 & 28.0 & 7.6 \\
III & 131.0 & Not available & 7.8 \\
\hline
\end{tabular}

Ninety one percent of the imported samples and $54 \%$ of local samples had salt content $>12 \%$. From Table 4 , it can be seen that only prawn samples contained average salt content less than $12 \%$. Compared to imported samples locally manufactured samples contained less amount of salt. Water activity of all the samples were less than the maximum level according to SLSI standards which is 0.75 except for tested prawn samples $(0.76)$ available at retail market.

Table 4 Average salt content (\%) in analyzed samples. I - Locally manufactured dried fish samples; II - Imported dried fish samples before distribution; III - Imported samples available at the retail market.

\begin{tabular}{lccc}
\hline Sample & I & II & III \\
\hline Tuna & 11.8 & 17.5 & 15.0 \\
Sprat & 14.0 & 14.6 & 15.0 \\
Catfish & 12.5 & 24.0 & 16.0 \\
Sailfish & 11.3 & 18.8 & 14.0 \\
Katta & 15.6 & 14.2 & 17.0 \\
Shark & 18.2 & 9.0 & 19.0 \\
Prawn & 12.0 & 8.1 & 10.0 \\
Hurulla & 10.4 & 16.4 & - \\
\hline
\end{tabular}

When considering all the parameters tested $15 \%$ of locally manufactured, $4 \%$ of imported samples obtained from retail market and $20 \%$ of imported samples before distribution were complying with Sri Lankan Standards. There was no significant difference (t-test; $\mathrm{p}>0.05$ ) between the analyzed parameters of locally manufactured samples and imported samples and also between imported samples before and after distribution to retail outlets.

\section{DISCUSSION}

Although none of the samples contained S. aureus in this study several studies conducted around the world have detected $S$. aureus in dried fish (Yam et al. 2015; Singh and Kulshrestha 1993; Suleiman and Mustafa 2012). S. aureus can survive in low water activity (aw) and can grow in media containing up to $18 \%$ salt (Sanjeev and Surendran 1996). Another study conducted in India has proved that if salt curing and sun drying procedures are followed accurately for fish, it is possible to get fish products free from enterotoxigenic staphylococci and its enterotoxins even from the raw material containing enterotoxigenic staphylococci (Sanjeev and Surendran 1996). High APC and yeast and mould counts were also recorded in a similar study conducted in India (Saritha et al. 2012).

In this study all the samples were negative for E.coli which is an indicator organism. Similar study conducted in Sudan has also reported that indicator organisms like coliforms and pathogens like Staphylococcus aureus were absent in tested dried fish samples after processing (Suleiman and Mustafa 2012). Hamjeer et al.(2006) have found that high concentrations of $\mathrm{NaCl}$ has an effect on morphology of E. coli and $S$. aureus cells and also $E$. coli cells were damaged extensively. This may be a reason for absence of $S$. aureus and $E$. coli in the tested samples of this study.

In a previous study conducted in Sri Lanka has found to contain histamine in dried-Skipjack tuna and dried sprats in $60.0 \%$ and $64.0 \%$ respectively (Gunarathne and Samarajeewa 1994). Also a significant amount of histamine has been found in dried mackerel and dried shrimp in India (Vijayan et al. 2003). Another study conducted in Sydney, Australia has found that dried anchovies contained an average value of $35 \mathrm{mg} / \mathrm{kg}$ histamine and reported values ranging from non-detected level to $483 \mathrm{mg} / \mathrm{kg}$ (NSW Food Authority 2009). According to a study conducted in Taiwan, of the dried fish samples analyzed, $30.4 \%$ contained histamine greater than $5 \mathrm{mg} / 100 \mathrm{~g}$, which was within the allowable limit of the US Food and Drug Administration (FDA) for scombroid fish and fishery products (Huang et al. 2010). According to FDA Guidelines (2011) for tuna, common dolphinfish (Coryphaena hippurus) and related fish, 


\section{P.H. Ginigaddarage et al.}

the toxicity level is $50 \mathrm{mg} / 100 \mathrm{~g}$ and $5 \mathrm{mg} / 100 \mathrm{~g}$ is the defect action level. In this study, average histamine values of all three categories of tuna (locally produced dried fish, imported dried fish before and after distribution to retail market) and locally manufactured dried fish of herring fall into defect action level of FDA limits. Reasons for elevated histamine levels can be raw material quality, handling and storage conditions.

Salt has the ability to reduce the water activity and preserve the food. In addition microbial cells loose water from cells as a result of osmotic shock due to salt. Therefore the microbial cells die or growth becomes slow (Potter and Hotchkiss 1995). Addition of salt to dried fish therefore is a benefit but the quality of salt should also be considered. Generally, when water activity is lower than 0.85 there is no microbial growth or toxin formation in food occur (Jonsson et al. 2007).

\section{CONCLUSION}

According to obtained results it can be seen that unacceptable percentages of both imported and locally manufactured dried fish in terms of APC, yeast and mould and histamine content are less than $50 \%$. Although the majority of the samples fall into acceptable category by percentage care must be taken to further reduce the unacceptable amount of dried fish by adopting better handling practices while preparing and storing as storage conditions may also play a key role in quality deterioration. $91 \%$ of the imported dried fish contained salt content $>12 \%$ and $54 \%$ of the local samples contained $>12 \%$ salt. Although high salt content maybe injurious to health, salt is a must to control spoilage. The only way to avoid this dilemma would be thorough washing prior to cooking, a practice done in Sri Lankan households anyway. Measures should be taken to produce dried fish in hygienic manner with good quality raw materials and routine checks should be done to imported dried fish to verify their quality and it is very important to check the microbial and chemical quality before they release to the market.

\section{Acknowledgements}

The authors wish to thank the staff of Institute of Post-Harvest Technology of National Aquatic
Resources Research and Development Agency (NARA), Sri Lanka for the support extended by them, Officials of Ministry of Health, Sri Lanka for providing samples and the management of NARA for providing funds to make this study a success.

\section{REFERENCES}

Chakrabarti, R. and P.R.G. Varma 2003. Fungi in salted and dried fish from coastal Andhra Pradesh. pp. 418-421. In: P.K. Surendran, P.T. Mathew, N. Thampuran, V.N. Nambiar, J. Joseph, M.R. Boopendranath, P.T. Lakshmanan and P.G.V. Nair (eds.). Seafood Safety. Society of Fisheries Technologists (India), Cochin.

FAO 1982. Reference Manual to Codes of Practices for Fish and Fishery Products. Food and Agriculture Organization, Rome.

FAO 2012. The State of World Fisheries and Aquaculture 2012. FAO Fisheries and Aquaculture Department, Rome. Available at http://www.fao.org/docrep/016/i2727e/i2727e.p df

Fellows, P. and A. Hampton 1992. Small- scale food processing - A guide for appropriate equipment. p. 158. Intermediate Technology Publications, Southampton Row, London.

Gunaratne, S and U. Samarajeewa 1994. Histamine and histamine producing bacteria in fish from Sri Lanka. Tropical Agricultural Research 6: 52 59.

Hajmeer, M., E. Ceylan, J.L.Marsden and D.Y. Fung 2006. Impact of sodium chloride on Escherichia coli O157:H7 and Staphylococcus aureusanalysed using transmission electron microscopy. Food Microbiology 23 (5): 446452.DOI:10.1016/j.fm.2005.06.005

Huang,Y., K.J. Liu, H.S. Hsieh, C.H. Hsieh, D. F. Hwang and Y. H.Tsai 2010. Histamine level and histamine forming bacteria in dried fish products sold in Penghu Island of Taiwan. Food Control 21:1234-1239.

DOI:10.1016/j.foodcont.2010.02.008

ISO 2004. Microbiology of food and animal feeding stuffs Determination of water activity ISO 21807:2004. International Organization for Standardization, ISO Central Secretariat, Switzerland. 


\section{P.H. Ginigaddarage et al.}

Jinadasa, B.K.K.K., C.K. Galhena and N.P.P. Liyanage 2015. Histamine formation and the freshness of yellowfin tuna (Thunusalbacares) stored at different temperatures. Cogent Food and Agriculture 1:1028735. https://doi.org/10.1080/23311932.2015.102873 5

Jónsson, A., G.A. Finnbogadóttir, G. Porkelsson, H. Magnússon, O. Reykdal and S. Arason 2007. Dried fish as health food.Matis-Food Research, Innovation \& Safety, Iceland.

Lilabati, H., W. Vishwanath and M. Singh 1999. Changes in bacterial and fungal quality during storage, Esomusdanricus of Manipur. Fishery Technology 36:36-39.

Ministry of Fisheries and Aquatic Resources Development 2016. [http://www.fisheries.gov.lk/content.php?cnid= ststc]

NSW Food Authority, 2009. Presence of histamine in anchovies. NSW 1811, Australia.

Pan, B.S. and D. James 1985. Histamine in marine products: Production by bacteria, measurement and prediction of formation. Fisheries Technical Paper no 252. Food and Agriculture Organization of the United Nations (FAO), Rome.

Potter, N.N., J.H. Hotchkiss 1995. Food Science Texts Series. $5^{\text {th }}$ Edn Chapman \& Hall, New York, 608p.

Prabhakaran, N. and R. Gupta, 1990. Handling, processing and marketing of tropical fish. Fishery Technology 27: 66 - 69 .

Ranasinghe, I., P. Ginigaddarage, S. Ariyawansa and S. Senadheera 2014. A comparative study on microbiological and chemical quality of dried fish retailed in Sri Lanka.Paper presented at SLCARP International Agricultural Research Symposium,11-12 August 2014, Colombo.Aquaculture and Fisheries, Book of abstracts, $122 \mathrm{p}$.

Sanjeev, S. and P.K. Surendran 1996. Fate of enterotoxigenic Staphylococci in fish subjected to curing. Fishery Technology 33(1): 66-68.

Saritha, K., K.I. Jayasantha, V. Aiyamperumal and J. Patterson 2012. Microbial and biochemical qualities of salted and sun dried seafoods of Cuddalore, Southeast coast of India. International Journal of Microbiological
Research 3(2): 138-143. DOI: 10.5829/idosi.ijmr.2012.3.2.63119

Singh, B.J. and S.B. Kulshrestha 1993. A study on prevalence of Staphylococcus aureus in fish and fish products and their public health significance. Indian Journal of Comparative Microbiology, Immunology and Infectious Diseases 14: 3-4.

Sri Lanka Standards 1991a. Microbiological Test Methods, Part 1: General guidance for enumeration of micro-organisms colony count technique, SLS 516: Part 1: 1991, Sri Lanka Standards Institution, Colombo, Sri Lanka.

Sri Lanka Standards 1991b. Microbiological Test Methods, Part 2: Enumeration of yeasts and moulds, SLS 516: Part 2: 1991, Sri Lanka standards Institution, Colombo, Sri Lanka.

Sri Lanka Standards 1982. Microbiological Test Methods, Part 3: Detection and enumeration of coliforms, faecal coliforms and Escherichia coli, SLS 516: Part 3: 1982, Sri Lanka Standards Institution, Colombo, Sri Lanka.

Sri Lanka Standards 1992. Microbiological Test Methods, Part 6: General guidance for enumeration of Staphylococcus aureus, SLS 516: Part 6: 1992, Sri Lanka Standards Institution, Colombo, Sri Lanka

Sri Lanka Standards 2007. Specification for dried fish, SLS 643:2007, Sri Lanka Standards Institution, Colombo, Sri Lanka.

Suleiman, A.M.E. and W.A. Mustafa 2012. Quality characteristics of dried fish obtained from Eldeim Area, Central Sudan. International Journal of Food Science and Nutrition Engineering 2(1): 1-6.

DOI: 10.5923/j.food.20120201.01

United States Food and Drug Administration (USFDA) 2011. Chapter 7: Scombrotoxin (histamine) formation. pp 113-152. In: Fish and Fisheries Products Hazards and Controls Guidance,United States Food and Drug Administration,U.S.A.

Vijayan, P.K., P.K. Surendran and J. Joseph 2003. Histamine in dried fish in seafood safety. pp. 336-341. In: P.K.Surendran, P.T. Mathew, N. Thampuran, V.N. Nambiar, J. Joseph, M.R. Boopendranath, P.T. Lakshmanan and P.G.V. Nair (eds), Seafood Safety. Society of Fisheries Technologists (India), Cochin. 
Yam, B.Z., M. Khomeiri, S. Amirkhani and M. Sabagh 2015. Microbial quality of salted dried fish sold near Capsian Sea, Iran. Basic Research Journal of Microbiology 2(4): 61-65. 